\title{
CHEMICAL, NUTRITIONAL AND SENSORY CHARACTERIZATION OF SWEET POTATO SUBMITTED TO DIFFERENT COOKING METHODS
}

\author{
Regiane Ogliari ${ }^{1}$ iD, Jaqueline Machado Soares ${ }^{2}$, Flávia Teixeira 2 iD, Kélin \\ Schwarz $^{3}$, Kátia Aparecida da Silva ${ }^{3}$, Dalton Luiz Schiessel ${ }^{1}$ iD , Daiana Novello ${ }^{1,2}$ \\ $凶$ (iD), \\ ${ }^{1}$ Department of Nutrition, State University of Midwest, Guarapuava, Brazil \\ ${ }^{2}$ Postgraduate Program Interdisciplinary in Community Development, State University of \\ Midwest, Guarapuava, Brazil \\ ${ }^{3}$ Department of Nutrition, Federal University of Triângulo Mineiro, 38025-350 Uberaba, Brazi
}

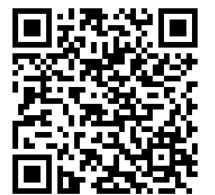

DOI: https://doi.org/10.29121/granthaalayah.v8.i10.2020.1881

Article Type: Research Article

Article Citation: Regiane Ogliari, Jaqueline Machado Soares, Flávia Teixeira, Kélin Schwarz, Kátia Aparecida da Silva, Dalton Luiz Schiessel, and Daiana Novello. (2020). CHEMICAL, NUTRITIONAL AND SENSORY

CHARACTERIZATION OF SWEET POTATO SUBMITTED TO DIFFERENT COOKING METHODS. International Journal of Research GRANTHAALAYAH, 8(10), 147-156. https://doi.org/10.29121/granthaa layah.v8.i10.2020.1881

Received Date: 01 October 2020

Accepted Date: 28 October 2020

Keywords:

Tuber Nutritional Value Nutrients

\section{ABSTRACT}

The objective was to evaluate different cooking methods effect on chemical, nutritional and sensory characteristics of sweet potatoes. Samples were subjected to four cooking methods: boiled in water, fried, microwaved and baked. In general, $\mathrm{pH}$, Titratable Acidity and Soluble Solids contents were altered by cooking methods. Reducing, Non-Reducing and Total Sugars levels increased after cooking, regardless of the method used. Levels of red and yellow were lower in tubers after the methods of boiled and baked, while the light reduced in all cooking processes. Cooking by boiled and fried increased Total Carotenoid content, reducing it in other methods. Except for boiled, all other processes increased Phenolic Compounds content. Ascorbic Acid content increased in all cooking processes, being higher for fried. Sweet potatoes cooked by boiled had higher moisture content and lower protein, lipid, carbohydrate and energy, while fried was the process that most elevated the content of these nutrients. Sensory scores were higher for sweet potatoes cooked in fried method. It is concluded that the processes of baked, boiled, fried and cooking in microwave alter chemical and nutritional characteristics of sweet potatoes. The tuber submitted to fried has greater sensory acceptability, however it is the least suitable for consumption due to high levels of fat and energy.

\section{INTRODUCTION}

Sweet potato (Ipomoea potatoes L.) belong to family Convolvulaceae [1] and are considered one of the main food crops in the world. The tuber is grown in tropical and subtropical regions, particularly in Asia, Africa, and Pacific. Asia and Africa are responsible for $95 \%$ of all world production [2]. Sweet potato trade occurs throughout all year, with the harvest taking place mainly in winter beginning [3]. The tuber is the $5^{\text {th }}$ most produced food in the world, reaching a production of 106,601,602 tons/year. In Brazil, its production reaches 525,814 tons/year, thus occupying

(C) 2020 The Author(s). This is an open access article distributed under the terms of the Creative Commons Attribution License, which permits unrestricted use, distribution, and reproduction in any medium, provided the original author and source are credited. 
Chemical, Nutritional and Sensory Characterization of Sweet Potato Submitted to Different Cooking Methods

the $17^{\text {th }}$ place as the most cultivated temporary crop [4]. Sweet potatoes are a basic crop in developing countries, as they have high yield potential, resistance, low cultivation requirements and high economic potential [5], [6]. The skin and pulp of the tuber may have different colors, which vary from pure white to intense purple [7].

Due to its favorable nutritional profile, sweet potatoes have been the focus research in recent years [8]. It has high levels of carbohydrate, dietary fiber, vitamins, and minerals $(\mathrm{K}, \mathrm{P}, \mathrm{Ca}, \mathrm{Mg}, \mathrm{Fe}, \mathrm{Mn}, \mathrm{Cu}) . \mathrm{In}$ addition, there is bioactive compounds presence, such as anthocyanins and phenolic acids, which contribute to the skin and pulp color. Also, high concentrations of vitamin C (6-10 mg $\left.100 \mathrm{~g}^{-1}\right)$ and $\beta$-carotene (273-400 $\mu \mathrm{g} 100 \mathrm{~g}^{-1}$ ) are observed, especially in orange-fleshed sweet potatoes [6], [8]. In human health, studies show that the tuber can have an antioxidant, hepatoprotective, anti-inflammatory, anti-tumor, antimicrobial and anti-aging effect, reducing risk of developing diabetes mellitus and obesity [8].

Sweet potatoes are usually cooked before consumption. The most used methods are fried, boiled, dehydration, baked, steaming, and cooking by microwaved [9], [10], [11]. Although cooking improves sensory, nutritional, digestibility and bioavailability product aspects, and cooking can promote some nutrients losses. Tian et al. [12] demonstrated that sweet potatoes submitted to fried showed reduction in levels of vitamin $\mathrm{C}(83.4 \%)$ and carotenoids (75.7\%), when compared to raw tubers. Baked methods ( $71.6 \%$ and $52 \%$, respectively), boiled ( $40.8 \%$ and $20.1 \%$, respectively) and microwaved cooking $(7.5 \%$ and $66.3 \%$, respectively) caused less losses of these compounds. In this context, the objective of this research was to evaluate the effect of different cooking methods on chemical, nutritional and sensory characteristics in sweet potatoes submitted to different cooking methods.

\section{MATERIALS AND METHODS}

\section{Vegetable Material}

Sweet potato samples were acquired in a supermarket located in Guarapuava, Paraná, Brazil. It was used $15 \mathrm{~kg}$ of sweet potato with purple skin and cream pulp, with a better visual aspect. Those with defects and/or that had a hugely different size and appearance were excluded.

\section{Cooking Methods}

The samples were washed in running water, with subsequent sanitization in sodium hypochlorite solution (150 ppm) for 15 minutes and bark and tips were discarded. The sweet potatoes were cut in the form of a toothpick of approximately $1 \mathrm{~cm} \times 1 \mathrm{~cm}$, in which $1 \mathrm{~kg}$ of raw tuber was reserved for the analysis of the chemical and nutritional compositions.

The sweet potato remainder was separated into 4 groups, being subjected to four different cooking methods: a) boiled in water, $3.5 \mathrm{~kg}$ were immersed in $4 \mathrm{~L}$ of boiling water $\left(100^{\circ} \mathrm{C}\right)$ and cooked for about 20 minutes; b) fried, $3.5 \mathrm{~kg}$ were immersed in $2.7 \mathrm{~L}$ of soybean oil $\left(180^{\circ} \mathrm{C}\right)$ and cooked for about 10 minutes; c) microwaved, $3.5 \mathrm{~kg}$ were distributed in glass bowls and cooked at power 8 for about 10 minutes and; d) baked, $3.5 \mathrm{~kg}$ were distributed in an aluminum pan and baked in a conventional oven $\left(180^{\circ} \mathrm{C}\right)$ for 40 minutes. In all methods the sweet potato was cooked until the material did not show resistance to perforation.

\section{Chemical and Nutritional Composition}

The raw and cooked sweet potatoes were dried in dehydrator (Pardal ${ }^{\circledR}$, Brazil) with air circulation $\left(65^{\circ} \mathrm{C}\right)$ for 48 hours. After drying, they remained at room temperature $\left(22^{\circ} \mathrm{C}\right)$ until completely cooled. Samples were crushed in domestic blender (Mondial ${ }^{\circledR}$, Brazil) and stored at - $20{ }^{\circ} \mathrm{C}$ in aluminum containers until evaluation.

The following chemical evaluations were carried out: $\mathrm{pH}$, measured using a bench pH meter (Tecnopon ${ }^{\circledR}$, MPA210 model, Brazil); Soluble Solids (SS), obtained by reading directly on an ABBE bench refractometer (Bel ${ }^{\circledR}$, model RMI/RMT, Brazil) [13]. The values were expressed in ${ }^{\circ}$ Brix; Titratable Acidity (TA), using the titrometric method [13] and the results expressed in \% citric acid; SS and TA ratio, which was obtained by dividing the values of SS and TA; Reducing Sugars (RS), Non-Reducing Sugars (NRS) and Total Sugars (TS), were evaluated using the Lane-Eynon

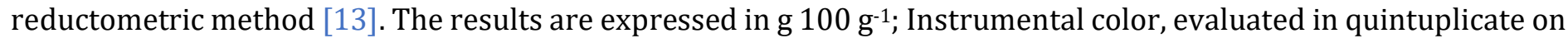
the surface of raw and cooked peeled sweet potatoes. The Comission Internatinale de E'clairage (CIE) $L^{*}$ (lightness), $a^{*}$ (red-green) and $b^{*}$ (yellow-blue) system was used, with a colorimeter reading (Konica Minolta ${ }^{\circledR}$, model Chroma Meter CR 4400, Japan), D65 illuminant and 10ํaㅁ. 
Regiane Ogliari, Jaqueline Machado Soares, Flávia Teixeira, Kélin Schwarz, Kátia Aparecida da Silva, Dalton Luiz Schiessel, and Daiana Novello

To determine nutritional composition, moisture content (g $100 \mathrm{~g}^{-1}$ ) was evaluated; ash (g $\left.100 \mathrm{~g}^{-1}\right)$; protein (g $100 \mathrm{~g}^{-1}$ ) [13]; lipid (g $100 \mathrm{~g}^{-1}$ ) [14]; carbohydrate (g $\left.100 \mathrm{~g}^{-1}\right)$ by difference (\% Carbohydrate $=100-(\%$ moisture + $\%$ protein $+\%$ lipid $+\%$ ash $+\%$ fibers) and; total energy value (kcal $\left.100 \mathrm{~g}^{-1}\right)$, using the values recommended by Merrill and Watt [15] for lipid (9 kcal g-1), protein ( $\left.4 \mathrm{kcal} \mathrm{g}^{-1}\right)$ and carbohydrate $\left(4 \mathrm{kcal} \mathrm{g}^{-1}\right)$. Ascorbic acid (Vitamin C) content was determined by titrometric method with 2.6 dichlorophenolindophenol [13];, modified by Benassi and Antunes [16] and results were expressed in mg $100 \mathrm{~g}^{-1}$.

Total carotenoids $\left(\mu \mathrm{g} \mathrm{g}^{-1}\right)$ were obtained by spectrophotometric analysis (Agillent Technologies ${ }^{\circledR}$, model Cary $60 \mathrm{UV}$, Malaysia) at $450 \mathrm{~nm}$ [17]. Phenolic compounds were measured by Follin-Ciocauteau spectrophotometric method [18], The reading was performed in spectrophotometer (Agillent Technologies ${ }^{\circledR}$, model Cary 60 UV, Malaysia) at $765 \mathrm{~nm}$, the results being expressed in mg of gallic acid equivalent (GAE) $100 \mathrm{~g}^{-1}$. Antiradical activity was evaluated using ABTS method (2,2-azinobis- [3-ethyl-benzothiazolin-6-sulfonic acid]), in both versions (hydrophilic and lipophilic) [19] and results were expressed in mmol of equivalents to the Trolox per gram of sample.

\section{Sensory Evaluation}

For the sensory test, sweet potatoes were cooked as described above. All samples were evaluated using an acceptance test applying a hedonic scale of nine points, with extremes ranging from very much disliked (1) to very much liked (9) [20]. Attributes related to appearance, aroma, taste, texture and overall acceptance were evaluated. Acceptability index (AI) was calculated by multiplying the average score informed by consumers to product by 100 , dividing result by maximum score given to product within the hedonic scale of 9.0 points.

Sixty tree untrained judges and sweet potatoes usual consumers have participated in sensory analyzes. Consumers were aged between 18 and 60 years old and were recruited among students and employees at the State University of the Midwest, Guarapuava, Paraná, Brazil. Each sample was served on white plates encoded with randomly selected 3-digit numbers, sequentially monadic [21] and under fluorescent lighting. After consuming each sample, evaluator was instructed to drink water to cleanse the taste. The samples were evaluated in triplicate and in separate sessions.

\section{Statistical Analysis}

Results were analyzed using analysis of variance (ANOVA). Data were compared using Tukey's test, with a significance level of $5 \%(p \leq 0.05)$ and $\mathrm{R}$ software was used to perform the statistical tests.

\section{Ethical Issues}

The study was conducted in accordance with the protocol approved by the Ethics Committee of Midwest State University, protocol number 2,201,325/2017.

\section{RESULTS AND DISCUSSIONS}

\section{Chemical and Nutritional Composition}

Chemical and nutritional composition results of raw and different methods of cooked sweet potatoes have been shown in Table 1.

Table 1: Chemical and nutritional composition average ( \pm standard deviation) of raw sweet potatoes and samples subjected to different cooking methods

\begin{tabular}{|c|c|c|c|c|c|}
\hline Parameter & Raw & Boiled & Fried & Microwaved & Baked \\
\hline Chemical composition & & & & & \\
\hline pH & $5.49 \pm 0.06^{\mathrm{c}}$ & $5.86 \pm 0.01^{\mathrm{a}}$ & $5.43 \pm 0.04^{\mathrm{c}}$ & $5.44 \pm 0.04^{\mathrm{c}}$ & $5.61 \pm 0.06^{\mathrm{b}}$ \\
\hline Titratable Acidity (\% citric acid) & $0.13 \pm 0.01^{\mathrm{c}}$ & $0.08 \pm 0.02^{\mathrm{d}}$ & $0.20 \pm 0.00^{\mathrm{ab}}$ & $0.21 \pm 0.01^{\mathrm{a}}$ & $0.17 \pm 0.02^{\mathrm{b}}$ \\
\hline Soluble Solids (o-Brix) & $2.83 \pm 0.08^{\mathrm{d}}$ & $4.08 \pm 0.06^{\mathrm{c}}$ & $6.67 \pm 0.07^{\mathrm{b}}$ & $11.08 \pm 0.09^{\mathrm{a}}$ & $10.92 \pm 0.3^{\mathrm{a}}$ \\
\hline $\begin{array}{c}\text { Soluble Solids/Titratable Acidity } \\
\text { (ratio) }\end{array}$ & $21.77 \pm 0.01^{\mathrm{d}}$ & $51.00 \pm 0.01^{\mathrm{b}}$ & $33.35 \pm 0.01^{\mathrm{c}}$ & $52.76 \pm 0.01^{\mathrm{b}}$ & $64.23 \pm 0.01^{\mathrm{a}}$ \\
\hline $\begin{array}{c}\text { Reducing Sugars (g 100 g-1) } \\
\text { Non-Reducing Sugars (g 100 g }-1)\end{array}$ & $2.41 \pm 0.02^{\mathrm{d}}$ & $3.31 \pm 0.04^{\mathrm{c}}$ & $11.29 \pm 0.09^{\mathrm{a}}$ & $11.85 \pm 0.08^{\mathrm{a}}$ & $8.12 \pm 0.00^{\mathrm{b}}$ \\
\hline
\end{tabular}


Chemical, Nutritional and Sensory Characterization of Sweet Potato Submitted to Different Cooking Methods

\begin{tabular}{|c|c|c|c|c|c|}
\hline Total Sugars (g $100 \mathrm{~g}^{-1}$ ) & $3.19 \pm 0.06^{\mathrm{e}}$ & $5.45 \pm 0.05^{\mathrm{d}}$ & $19.22 \pm 0.01^{\mathrm{a}}$ & $17.23 \pm 0.00^{\mathrm{b}}$ & $16.68 \pm 0.04^{c}$ \\
\hline$L^{*}$ & $80.50 \pm 0.57 \mathrm{a}$ & $52.25 \pm 1.08^{d}$ & $62.60 \pm 3.79 c$ & $73.45 \pm 1.53^{\mathrm{b}}$ & $52.75 \pm 1.20^{\mathrm{d}}$ \\
\hline$a^{*}$ & $-1.24 \pm 0.45^{a}$ & $-6.02 \pm 0.51^{c}$ & $-1.84 \pm 0.88^{a}$ & $-2.00 \pm 0.56^{\mathrm{ab}}$ & $-2.71 \pm 0.76^{b}$ \\
\hline$b^{*}$ & $23.27 \pm 0.46^{b}$ & $15.18 \pm 0.75^{c}$ & $23.04 \pm 2.28^{\mathrm{b}}$ & $32.20 \pm 1.87 \mathrm{a}$ & $15.32 \pm 1.27 \mathrm{c}$ \\
\hline \multicolumn{6}{|l|}{ Nutritional composition } \\
\hline Moisture (g $100 \mathrm{~g}^{-1}$ ) & $73.48 \pm 0.03^{\mathrm{b}}$ & $83.70 \pm 0.07 \mathrm{a}$ & $42.10 \pm 0.04 \mathrm{e}$ & $61.43 \pm 0.08^{c}$ & $59.73 \pm 0.09^{d}$ \\
\hline Ash (g $\left.100 g^{-1}\right)$ & $0.62 \pm 0.05^{c}$ & $0.37 \pm 0.08^{\mathrm{d}}$ & $1.02 \pm 0.09 \mathrm{~b}$ & $0.97 \pm 0.07 \mathrm{~b}$ & $1.42 \pm 0.03^{\mathrm{a}}$ \\
\hline Protein (g $\left.100 \mathrm{~g}^{-1}\right)$ & $1.16 \pm 0.06^{\mathrm{d}}$ & $0.51 \pm 0.08^{\mathrm{e}}$ & $2.43 \pm 0.08^{\mathrm{a}}$ & $1.80 \pm 0.06^{\mathrm{b}}$ & $1.39 \pm 0.09^{c}$ \\
\hline Lipid (g $100 \mathrm{~g}^{-1}$ ) & $0.05 \pm 0.07 \mathrm{c}$ & $0.04 \pm 0.07 \mathrm{c}$ & $7.38 \pm 0.09^{\mathrm{a}}$ & $0.09 \pm 0.09 \mathrm{c}$ & $0.38 \pm 0.04^{b}$ \\
\hline Carbohydrate (g $100 \mathrm{~g}^{-1}$ ) & $24.70 \pm 0.18^{c}$ & $15.38 \pm 0.13^{\mathrm{d}}$ & $47.08 \pm 0.22^{\mathrm{a}}$ & $35.71 \pm 0.17 \mathrm{~b}$ & $37.08 \pm 0.25^{b}$ \\
\hline Total Energy Value (kcal $\left.100 \mathrm{~g}^{-1}\right)$ & $103.83 \pm 0.63^{\mathrm{d}}$ & $63.94 \pm 0.43^{\mathrm{e}}$ & $264.41 \pm 0.89^{a}$ & $150.84 \pm 0.65^{c}$ & $157.30 \pm 0.89^{b}$ \\
\hline Total Carotenoid $\left(\mu \mathrm{g} \mathrm{g}^{-1}\right)$ & $3.10 \pm 0.01^{\mathrm{c}}$ & $3.49 \pm 0.01^{b}$ & $6.29 \pm 0.02^{\mathrm{a}}$ & $2.81 \pm 0.01^{\mathrm{d}}$ & $2.72 \pm 0.02^{\mathrm{e}}$ \\
\hline $\begin{array}{l}\text { Phenolic Compounds (mg GAE } 100 \\
\mathrm{~g}^{-1} \text { ) }\end{array}$ & $2.88 \pm 0.01^{\mathrm{d}}$ & $1.54 \pm 0.00^{\mathrm{e}}$ & $4.88 \pm 0.01^{\mathrm{a}}$ & $3.50 \pm 0.01^{c}$ & $4.76 \pm 0.01^{b}$ \\
\hline Ascorbic acid (mg $\left.100 \mathrm{~g}^{-1}\right)$ & $6.68 \pm 0.09 \mathrm{~d}$ & $8.56 \pm 0.10^{\mathrm{bc}}$ & $11.90 \pm 0.04^{\mathrm{a}}$ & $9.00 \pm 0.07 \mathrm{~b}$ & $7.84 \pm 0.08^{c}$ \\
\hline
\end{tabular}

Distinct letters in row are significantly different by the Tukey's test $(p<0.05)$; Results reported in wet weight basis.

The boiled and baking processes increased the sweet potatoes $\mathrm{pH}$ value $(p<0.05)$, while frying and microwaved cooking did not change this parameter compared to raw product $(p>0.05)$. A higher TA content was found in fried and cooked in the microwave sweet potatoes, and lower for those cooked by boiled. In the water presence, there was an increase in the phosphorylase enzyme activity that degrades starch. This resulted in lower sugars availability sugars in sweet potato, necessary for acids formation, reducing the product acidity. In addition, water causes damage to the tuber cell wall, which causes loss and dilution of organic acids to the water, thus increasing the $\mathrm{pH}$ of product [2], [22], [23].

Sweet potatoes cooking promoted an increase in SS in all processes $(p<0.05)$. This happens due to tuber exposure to high temperatures, which increases cell permeability, causing greater enzyme activity such as invertase and phosphorylase, which act in breaking down starch into sugars. Tubers submitted cooked in the microwave and baked showed higher SS levels. This parameter was also significantly higher for fried compared to boiled, corroborating the literature [24]. The large amount of water present in boiled method causes greater starch solubility, facilitating its loss to aqueous milieu. In the microwave and baked cooked methods, the tuber dehydrates due to the water loss due to high temperatures, which facilitates the starch exposure to enzymes that are responsible for its degradation. Higher SS/TA ratio was observed for baked sweet potatoes and lower for fries. The presence of sugars and acids in sweet potatoes is relevant to taste perception, so high SS/TA ratios can increase consumer acceptance [25].

Reducing, non-reducing and total sugars levels were increased after cooking sweet potatoes $(p<0.05)$, regardless of the method used. This effect occurs because about 20\% of sweet potatoes are composed of starch. During cooking at high temperatures, formation of monosaccharides and disaccharides occurs through the starch decomposition [26], [27]. In addition, sucrose, which is the main sugar present in sweet potatoes [28] is converted into fructose and glucose, which increases the reducing sugars content into the tuber [27]. Higher contents of RS, NRS and TS were observed in cooking by microwaved/fried, baked and fried, respectively. The boiled process was the one with the lowest levels in these evaluations, due to dilution and loss of glucose, fructose and sucrose to cooking water [29]. Similar results were observed by Chan et al. [27] and Hou et al. [30], who reported an increase in RS, NRS and TS in baked sweet potatoes, and by Yang et al. [29] and Murniece et al. [31] in sweet potato fries.

Cooking promoted reduction in sweet potatoes lightness, especially in boiled and baking methods, which made products darker. In these processes, greater enzymatic reaction occurs, favoring starch hydrolysis and product luminosity reduction. Microwave cooking, on the other hand, was one that least interfered in the $L^{*}$ value, since irradiation reduces starch availability for enzymatic action, which reduces hydrolysis while preserving the starch's crystallinity [29], [32], [33]. According to Feltran et al. [22], reduction in luminosity in fried method is explained by starch conversion into sugars, which contributes to tuber browning. The raw sweet potato has greenish color (negative $a^{*}$ value), which increases in presence of oxygen and light. The enzymes peroxidase and polyphenol 
Regiane Ogliari, Jaqueline Machado Soares, Flávia Teixeira, Kélin Schwarz, Kátia Aparecida da Silva, Dalton Luiz Schiessel, and Daiana Novello

oxidase are responsible for this effect, since they act on water-soluble oxidizing compounds, such as ascorbic acid, for example [33], [34].

The red content $\left(a^{*}\right)$ was lower in samples cooked by baked and, especially, in those submitted to boiled, compared to fried process. There was a significant increase in the $b^{*}$ (yellow) value of sweet potatoes after cooking with microwaved, while boiled and baking methods reduced this parameter. As previously reported, enzymatic action is more pronounced for baking and dipping methods in sweet potatoes. Thus, greater food oxidation is observed, which causes a greener and less yellow color (lower values of $a^{*}$ and $b^{*}$, respectively) [29], [35]. In general, raw sweet potatoes cooked by different cooking methods (boiled, fried, baked and microwaved) can be considered light in color, since all $L^{*}$ values were greater than $50 \%$, with a yellow hue $\left(b^{*}\right)$ and green undertone $\left(a^{*}\right)$ [36].

The moisture content was higher in sweet potatoes cooked by boiled compared to other methods, being lower for fried process $(p<0.05)$. In general, cooking processes have increased ash content, especially baked. However, in boiled method caused reduction in mineral content compared to raw tuber. Sweet potato submitted to boiled process also had the lowest levels of protein, lipid, carbohydrate, and energy, since the leaching process into water occurs [23]. The other methods increased the content of these nutrients in product, mainly for fried $(p<0.05)$. It is noteworthy that when food is cooked on oil, there is significant increase in lipid and, consequently, energy, so other methods are more suitable for consumption, since a high fat intake may increase the non-chronic diseases communicable diseases risk [37].

Cooking by baked and microwaved methods promoted a decrease in carotenoids levels, especially for baked process. In these processes, it appears that the temperature rises rapidly, which destroys some nutrients such as carotenoids [33], which are highly unsaturated [38], as observed in other studies [39], [40]. The methods of boiled and fried increased the carotenoids content compared to raw sweet potatoes, being higher for fried $(p<0.05)$, corroborating with the literature [39], [41]. According to Wu et al. [39], the possible increase in carotenoid content is due to the greater capacity for extracting beta-carotene due to changes in the cell wall structure caused by oil and increased temperature. Furthermore, carotenoids linked to some proteins dissociate in water, which increases their content.

Higher levels of phenolic compounds were found in fried process, followed by baked and microwaved, all of which are higher than the phenolic content of raw sweet potatoes, as found by Bellail et al. [42]. Phenolic compounds have some stability when exposed to high temperatures [43], in addition, heat increases the release of phenolic compounds through the hydrolysis of glycosidic bonds. Another factor is that heat, inactivates the enzyme polyphenol oxidase, which is responsible for degradation of these compounds in fresh tuber [44]. The boiled method in water was one with the lowest phenolic compounds content. including when compared to raw potatoes $(p<0.05)$, results that are in accordance with the literature [45], [46]. The loss of these compounds by leaching is the main responsible for this reduction since the phenolic compounds are hydrophilic [48].

All cooking methods showed an increase in ascorbic acid content, being higher for fried $(p<0.05)$. Cooking alters tuber cell wall matrix, facilitating vitamin $\mathrm{C}$ release in the product. In addition, cooking inactivates enzyme ascorbic acid oxidase [44], factors that may explain the higher vitamin C content after cooking sweet potatoes. Similar results have been observed in other studies [44], [47], [48]. Figure 1 shows the results of the antioxidant capacity of sweet potatoes submitted to different cooking methods.

Baked and microwaved cooking increased lipophilic antioxidant capacity in sweet potatoes, while boiled and fried processes reduced this parameter when compared to raw sweet potatoes. When tuber is cooked by oven and microwave, cell modification occurs due to dry heat, which makes lipophilic antioxidant compounds more available [32], [40], [49]. Boiled method showed the lowest lipophilic antioxidant capacity due to leaching [50], [51], [52]. In the fried case, there may be losses of fat-soluble compounds to the oil, reducing lipophilic antioxidant capacity [10], [40].

Fried and baked processes increased hydrophilic antioxidant capacity of sweet potatoes. In the case of fried, the heat of the oil is transferred to food surface and, when it reaches the center, moisture mobilizes to the surface, making hydrophilic antioxidant compounds more available [53], [40]. The baked method causes a structural change in tuber, due to dry heat, which increases the availability of hydrophilic antioxidant compounds [40]. There was a reduction in hydrophilic antioxidant capacity in cooking process by boiled, similarly to that verified for lipophilic antioxidant capacity. In microwave cooking, there was also less hydrophilic antioxidant capacity, which is due to dryness of the tuber and consequent dehydration [32], [40], [49]. 


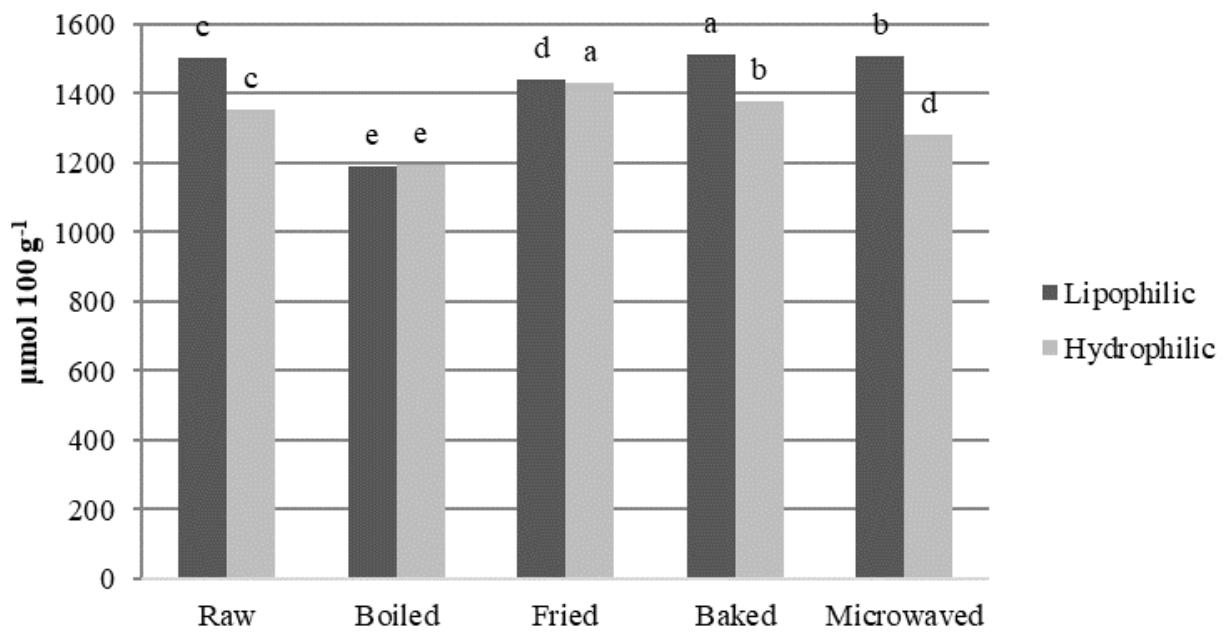

Figure 1: Lipophilic and hydrophilic antioxidant capacity of raw sweet potatoes and submitted to different cooking methods.

Distinct letters in column are significantly different by the Tukey's Test $(p<0.05)$; Results reported in wet weight basis.

\section{Sensory Evaluation}

Table 2 describes the sensory analysis results of sweet potatoes submitted to different cooking methods.

Table 2: Sensory scores (average \pm standard deviation) obtained in sweet potatoes evaluation submitted to different cooking methods

\begin{tabular}{|c|c|c|c|c|}
\hline Parameter & Boiled & Fried & Microwaved & Baked \\
\hline Appearance & $6.00 \pm 2.07^{\mathrm{ab}}$ & $6.85 \pm 1.86^{\mathrm{a}}$ & $5.68 \pm 1.92^{\mathrm{b}}$ & $5.53 \pm 1.90^{\mathrm{b}}$ \\
\hline AI $\%)$ & 66.66 & 76.11 & 63.11 & 61.44 \\
\hline Aroma & $5.73 \pm 1.65^{\mathrm{b}}$ & $7.19 \pm 1.53^{\mathrm{a}}$ & $6.26 \pm 1.77^{\mathrm{b}}$ & $6.41 \pm 1.70^{\mathrm{b}}$ \\
\hline AI (\%) & 63.66 & 79.88 & 69.55 & 71.22 \\
\hline Taste & $4.85 \pm 1.98^{\mathrm{c}}$ & $8.14 \pm 0.94^{\mathrm{a}}$ & $6.23 \pm 2.02^{\mathrm{b}}$ & $6.87 \pm 1.80^{\mathrm{b}}$ \\
\hline AI (\%) & 50.88 & 90.44 & 69.22 & 76.33 \\
\hline Texture & $5.14 \pm 2.20^{\mathrm{c}}$ & $7.22 \pm 1.68^{\mathrm{a}}$ & $5.93 \pm 2.19^{\mathrm{bc}}$ & $6.33 \pm 1.99^{\mathrm{ab}}$ \\
\hline AI (\%) & 57.11 & 80.22 & 65.88 & 70.33 \\
\hline Color & $5.98 \pm 1.90^{\mathrm{b}}$ & $7.15 \pm 1.85^{\mathrm{a}}$ & $5.76 \pm 1.90^{\mathrm{b}}$ & $5.69 \pm 1.92^{\mathrm{b}}$ \\
\hline AI (\%) & 66.44 & 79.44 & 64.00 & 63.22 \\
\hline Global Acceptance & $4.98 \pm 1.87 \mathrm{c}$ & $7.90 \pm 1.07^{\mathrm{a}}$ & $6.28 \pm 2.10^{\mathrm{b}}$ & $6.60 \pm 1.71^{\mathrm{b}}$ \\
\hline AI (\%) & 55.33 & 87.77 & 69.77 & 73.33 \\
\hline
\end{tabular}

Distinct letters in row are significantly different by the Tukey's test $(p<0.05)$; AI: Acceptability Index.

There was a significant difference $(p<0.05)$ in sweet potatoes acceptability submitted to cooking methods. Higher grades for appearance were obtained for fried compared to baked and microwaved cooking processes. The other methods were not statistically different $(p>0.05)$. Fried process dehydrates the starch granules, forming a thick, dry and crunchy surface. In addition, it also gives golden color to sweet potatoes, which is expected in fried products [12], [24]. This effect does not occur in microwaved cooking and baked processes, since heat causes water evaporation and modifies the tuber cell structure, leading to dehydration [32].

For attributes of aroma and color, greater acceptability $(p<0.05)$ was observed for sweet potatoes submitted to fried, compared to other samples. A similar result was verified for taste and global acceptance. However, the average score for sweet potatoes cooked by boiled was lower $(p<0.05)$ than other processing. In fried method, oil incorporates different types of fatty acids into the product, which improve palatability, taste and aroma. Other compounds such as aldehydes, ketones, hydrocarbons and alcohols are also formed in this process, promoting fatty aroma notes in the product, which can be pleasant to consumers. However, research has already shown that some 
Regiane Ogliari, Jaqueline Machado Soares, Flávia Teixeira, Kélin Schwarz, Kátia Aparecida da Silva, Dalton Luiz Schiessel, and Daiana Novello

individuals prefer foods with high fat levels [24], [54]. Factors related to creaminess, spreadability and fluidity that fat produces in the mouth, associated with the sensation of pleasure and satiety released by the brain, are considered the main responsible for this type of preference [54], [55].

Sweet potato fried showed higher notes for texture, compared to that submitted to boiled and microwaved methods, which did not differ from each other $(p>0.05)$. Similar results were observed by Caetano et al. [24] evaluating baked sweet potato chips, fried in oil and by air fryer. In the water cooking process, the fibers soften [29], in contrast to microwaved cooking, which makes the food stiffer and drier. In this case, the product loses moisture through evaporation, since there is a migration of water from the sweet potato core to extremities, which limits the starch gelatinization.

These changes in sweet potato texture generally reduce acceptability by consumers [29], [32], as seen in the present study. Although the fried method has shown better sensory acceptability, the baked process has also received good acceptance by consumers, since it obtained $\mathrm{AI} \geq 70 \%$ [56], for attributes of aroma, taste, texture and global acceptance. Furthermore, this method is also more favorable to consumption since it retains a greater amount of minerals, vitamin C, carotenoids and contains a lower fat content compared to fried [12], [32]. A diet with reduced fat content and associated with healthy habits can decrease the risk of developing chronic non-communicable diseases such as high blood pressure and diabetes mellitus [57], [58].

\section{CONCLUSIONS}

It is concluded that processes of baked, boiled, fried and cooking in the microwave alter chemical and nutritional characteristics of sweet potatoes. Fried and microwaved cooking processes are the ones that most interfere in chemical composition of sweet potatoes, reducing $\mathrm{pH}$ levels and increasing titratable acidity concentration, reducing sugars and red content. The fried tuber has the highest sensory acceptability by consumers and the highest nutritional content. However, it is the least suitable process for human consumption since it increases the fat and energy content of the product. The boiled method promotes the greatest losses in relation to chemical and nutritional composition of sweet potatoes, in addition to being the least accepted sensorial in general.

\section{SOURCES OF FUNDING}

This research received no specific grant from any funding agency in the public, commercial, or not-for-profit sectors.

\section{CONFLICT OF INTEREST}

The author have declared that no competing interests exist.

\section{ACKNOWLEDGMENT}

None.

\section{REFERENCES}

[1] Shekhar S, Mishra D, Buragohain AK, Chakraborty S, Chakraborty N. Comparative analysis of phytochemicals and nutrient availability in two contrasting cultivars of sweet potato (Ipomoea batatas L.). Food Chemistry. 2015;173(1):957-965.

[2] El Sheikha AF, Ray RC. Potential impacts of bioprocessing of sweet potato: Review. Critical Reviews in Food Science and Nutrition. 2015;57(3):455-471.

[3] Ikanone CEO, Oyekan PO. Effect of boiling and frying on the total carbohydrate, vitamin C and mineral contents of irish (Solanun tuberosum) and sweet (Ipomea batatas) potato tubers. Nigerian Food Journal. 2014;32(2):33-39. 
Chemical, Nutritional and Sensory Characterization of Sweet Potato Submitted to Different Cooking Methods

[4] Food and Agriculture Organization of the United Nations (FAO). Storage and processing of roots and tubers in the tropics. 2015. Available online: http://www.fao.org/3/X5415E/x541 5e01.htm. (accessed on: 21 Sept. 2020).

[5] Laurie S, Faber M, Adebola P, Belete A. Biofortification of sweet potato for food and nutrition security in South Africa. Food Research International. 2015;76(1):962-970.

[6] Chandrasekara A, Kumar TJ. Roots and tuber crops as functional foods: A Review on phytochemical constituents and their potential health benefits. International Journal of Food Science. 2016;2016(1):1-15.

[7] Zheng Y, Wang Q, Li B, Lin L, Tundis R, Loizzo MR, Zheng B, Xiao J. Characterization and prebiotic effect of the resistant starch from purple sweet potato. Molecules. 2016;21(7):932.

[8] Wang S, Nie S, Zhu F. Chemical constituents and health effects of sweet potato. Food Research International. 2016;89(1):90-116.

[9] Zhu F, Wang S. Physicochemical properties, molecular structure, and uses of sweet potato starch. Trends in Food Science \& Technology. 2014;36(2):68.

[10] Sun H, Mu T, Xi L, Song Z. Effects of Domestic Cooking Methods on polyphenols and antioxidant activity of sweet potato leaves. Journal of Agricultural and Food Chemistry. 2014;62(36):8982-8989.

[11] Mennah-Govela YA, Bornhorst GM. Acid and moisture uptake in steamed and boiled sweet potatoes and associated structural changes during in vitro gastric digestion. Food Research International. 2016;88(1):247255.

[12] Tian J, Chen S, Shi J, Chen J, Liu D, Cai Y, Ogawa Y, Ye X. Microstructure and digestibility of potato strips produced by conventional frying and air-frying: An in vitro study. Food Structure. 2017;14(1):30-35.

[13] Association of Official Analytical Chemistry (AOAC). Official methods of analysis of AOAC International. Gaithersburg: AOAC; 2011.

[14] Bligh EG, Dyer WJ. A rapid method of total lipid extraction and purification. Canadian Journal of Biochemistry and Physiology. 1959;37(8):911-917.

[15] Merrill AL, Watt BK. Energy value of foods: basis and derivation. Washington: Department of Agricultura Handbook; 1973.

[16] Benassi MT, Antunes AJ. Comparison of metaphosphoric and oxalic acids as extractants solutions for the determination of vitamin $C$ in selected vegetables. Brazilian Archives of Biology and Technology. Curitiba. 1988;31(4)507-513.

[17] Rodriguez-Amaya D. Guide to carotenoid analysis in foods. International Life Sciences. Washington: Institute Press; 2001.

[18] Bucić-Kojić A, Planinić M, Tomas S, Bilić M, Velić D. Study of solid-liquid extraction kinetics of total polyphenols from grape seeds. Journal of Food Engineering. 2007;81(1):236-242.

[19] Miller NJ, Sampson J, Candeias LP, Bramley PM, Rice-evans CA. Antioxidant activities of carotenes and xanthophylls. FEBS letters. 1996;384(3)240-242.

[20] Meilgaard M, Civille GV, Carr BT. Sensory evaluation techniques. Florida: CRC Pres; 1999.

[21] Macfie HJ, Bratchell NS, Greenhoff K, Vallis LV. Designs to balance the effect of order of presentation and firstorder carry-over effects in hall tests. Journal of Sensory Studies. 1989;4(2):129-148.

[22] Feltran JC, Lemos LB, Vieites RL. Technological quality and utilization of potato tubers. Scientia Agricola. 2004;61(6):598-603.

[23] Armesto J, Limia-Gómez L, Carballo J, Martínes S. Effects of different cooking methods on some chemical and sensory properties of galega kale. International Journal of Food Science and Technology. 2016;51(9)20712080.

[24] Caetano PK, Mariano-Nasser FAC, Mendonça VZ, Furlaneto KA, Daiuto ER, Viettes RL. Physicochemical and sensory characteristics of sweet potato chips undergoing different cooking methods. Food Science and Technology. 2017;38(3)434-440.

[25] Jayasena V, Cameron I. Brix/Acid ratio as a predictor of consumer acceptability of crimson seedless table grapes. Journal of Food Quality. 2008;31(3)736-750.

[26] Aina AJ, Falade KO, Akingbala JO, Titus P. Physicochemical properties of twenty-one Caribbean sweet potato cultivars. International Journal of Food Science and Technology. 2009;44(1)1696-1704.

[27] Chan C, Chiang C, Lai Y, Huang C, Kao S, Liao W. Changes in sugar composition during baking and their effects on sensory atributes of baked sweet potatos. Journal of Food Science and Tecnology. 2014;52(12)4072-4077. 
Regiane Ogliari, Jaqueline Machado Soares, Flávia Teixeira, Kélin Schwarz, Kátia Aparecida da Silva, Dalton Luiz Schiessel, and Daiana Novello

[28] Zhang Z, Wheatley CC, Cork H. Biochemical changes during storage of sweet potato roots differing in dry matter content. Postharvest Biology Technology. 2002;24(1)317-325.

[29] Yang Y, Achaerandio I, Pujola M. Effect of the intensity of cooking methods on the nutritional and physical properties of potato tubers. Food Chemistry. 2016;197(1)1301-1310.

[30] Hou F, Mu T, Ma M, Blecker C. Optimization of processing technology using response surface methodology and physicochemical properties of roasted sweet potato. Food Chemistry. 2018;278(1)136-143.

[31] Murniece I, Karklina D, Galoburda R, Santare, D. Skrabule I, Costa HS. Nutritional composition of freshly harvested and stored Latvian potato (Solanum tuberosum L.) varieties depending on traditional cooking methods. Journal of Food Composition and Analysis. 2011;24(1)699-710.

[32] Teruel MR, Gordon MH, Linares MB, Garido MD, Chaoruangrit A, Niranjan. K. Comparative study of the characteristics of french fries produced by deep fat frying and air frying. Journal of Food Science. 2015;80(2)249-258.

[33] Guo Q, Sun W, Cheng J, Han Z. Microwave processing techniques and their recent applications in the food industry. Trends in Food Science \& Technology. 2017;67(1)236-247.

[34] Fennema 0, Damodaran S, Parkin K. Química de alimentos de Fennema. 4ed. Porto Alegre: Artmed; 2010.

[35] Romani S, Rocculi P, Mendoza F, Dalla Rosa M. Image characterization of potato chip appearance during frying. Journal of Food Engineering. 2009;93(1)487-494.

[36] Konica Minolta. Precise color communication. Avaliable online: http://www.konicaminoltaeurope.com. (accessed on: 21 Sept 2020).

[37] Defu M, Sakai H, Wakabayashi C, Kwon J, Lee Y, Liu S, Wan P, Sasao K, Ito K, Nishihara, Wang P. The prevalence and risk factor control associated with noncommunicable diseases in China, Japan, and Korea. Journal of Epidemiology. 2017;27(12)568-573.

[38] Blessington T, Nzaramba MN, Scheuring DC, Hale AL, Reddivari L, Miller JC. Cooking methods and storage treatments of potato: Effects on carotenoids. antioxidant activity. and phenolics. American Journal of Potato Research. 2010;87(6)479-491.

[39] Wu X, Sun C, Yang L, Zeng G, Liu Z, Li Y. $\beta$-carotene content in sweet potato varieties from China and the effect of preparation on $\beta$-carotene retention in the Yanshu No. 5. Innovative Food Science \& Emerging Technologies. 2008;9(1)581-586.

[40] Tian J, Chen J, Feiyan L, Chen S, Chen J, Liu D, Ye X. Domestic cooking methods affect the phytochemical composition and antioxidant activity of purplefleshed potatoes. Food Chemistry. 2016;197(1)1264-1270.

[41] Kidmose U, Christensen LP, Agili SM, Thilsted SH. Effect of home preparation practices on the content of provitamin A carotenoids in coloured sweet potato varieties (Ipomoea batatas Lam.). Innovative Food Science and Emerging Technologies. 2007;8(1)399-406.

[42] Bellail AA, Shaltout OE, Youssef MM, Gamal AMA. Effect of home-cooking methods on phenolic composition and antioxidant activity of sweetpotato (Ipomoea batatas (L.) Lam.) cultivars grown in egypt. food and nutrition sciences. 2012;3(4)490-499.

[43] Jiménez-Monreal AM, García-Diz L, Martínez-Tomé M, Mariscal M, Murcia MA. Influence of cooking methods on antioxidant activity of vegetables. Journal of Food Science. 2009;74(1)97-103.

[44] Dincer C, Karaoglan M, Erden F, Tetik N, Topuz A, Ozdemir F. Effects of baking and boiling on the nutritional and antioxidant properties of sweet potato [Ipomoea batatas (L.) Lam.] Cultivars. Plant Foods for Human Nutrition. 2011;66(4)341-347.

[45] Takenaka M, Nanayama K, Isobe S, Murata M. Changes in caffeic acid derivatives in sweet potato (Ipomoea batatas L.) during cooking and processing. Bioscience, Biotechnology and Biochemistry. 2006;70(1)172-177.

[46] Jung J, Lee S, Kozukue N, Levin C, Friedman M. Distribution of phenolic compounds and antioxidative activities in parts of sweet potato (Ipomoea batata L.) plants and in home processed roots. Journal of Food Composition and Analysis. 2011;24(1)29-37.

[47] Huang Y, Chang Y, Shao Y. Effects of genotype and treatment on the antioxidant activity of sweet potato in Taiwan. Food Chemistry. 2006;98(1)529-538.

[48] Navarre DA, Shakya R, Holden J, Kumar S. The effect of different cooking methods on phenolics and vitamin C in developmentally young potato tubers. American Journal of Potato Research. 2010;87(4)350-359.

[49] Ruiz-Rodriguez A; Marín FR, Ocaña A, Soler-Rivas C. Effect of domestic processing on bioactive compounds. Phytochemistry Reviews. 2008;7(2)345-384. 
[50] Andlauer W, Stumpf C, Hubert M, Rings A, Fürst P. Influence of cooking process on phenolic marker compounds of vegetables. International Journal for Vitamin and Nutrition Research. 2003;73(2)162-159.

[51] Ismail A, Marjan ZM, Foong CW. Total antioxidant activity and phenolic content in selected vegetables. Food Chemistry. 2004;87(4)581-586.

[52] Zhang D, Hamauzu Y. Phenolics. ascorbic acid. carotenoids and antioxidant activity of broccoli and their changes during conventional and microwave cooking. Food Chemistry. 2004;88(4)503-509.

[53] Gokmen V, Palazoglu TK, Senyuva HZ. Relation between the acrylamide formation and time-temperature history of surface and core regions of French fries. Journal of Food Engineering. 2006;77(4)972-976.

[54] Guichard E, Cuspinera VG, Feron G. Physiological mechanisms explaining human differences in fat perception and liking in food spreads-a review. Trends in Food Science \& Technology. 2018;74(1)46-55.

[55] Rolls E. Taste, olfactory and food reward value processing in the brain. Progress in Neurobiology. 2015;127(1)64-90.

[56] Corradini SAS, Madrona GS, Visentainer JV, Bonafe EG, Carvalho CB, Roche PM, Prado IN. Sensorial and fatty acid profile of ice cream manufactured with milk of crossbred cows fed palm oil and coconut fat. Journal of Dairy Science. 2014;97(11)6745-6753.

[57] Bauer UE, Briss PA, Goodman RA, Bowman BA. Prevention of chronic disease in the 21st century: elimination of the leading preventable causes of premature death and disability in the USA. The Lancet. 2014;384(9937)45-52.

[58] Murphy EA, Velasquez KT, Herbert KM. Influence of high-fat diet on gut microbiota: a driving force for chronic disease risk. Current Opinion in Clinical Nutrition and Metabolic Care. 2015;18(5)515-520. 